\title{
Comparison of the growing habit of peach varieties trained to caldron and slender spindle crowns
}

\author{
Szőke, S. \& Csihon, Á. \\ University of Debrecen, Centre of Agricultural Sciences and Engineering, Faculty of Agronomy, \\ Institute of Horticultural Science H-4032 Debrecen, Böszörményi str 138, Hungary
}

\begin{abstract}
Summary: Six peach varieties ('Red Moon', 'Early Redhaven', 'Rich Lady', 'Suncrest', 'Silver King', 'Royal Glory') grafted on seedling stock have been trained alternatively, to caldron (kettle) and to slender spindle, are compared in dormant stage regarding their variety-specific growing habits. According to our results, marked differences have been stated in vegetative vigour of varieties measured as the length, thickness and number of shoots. The caldron crowns displayed more vigour whereas the spindle trees produced more balanced and moderately growing shoots. The differences due to varieties were more conspicuous that due to the training. An intrinsic knowledge of growing habits of varieties may facilitate the development of variety-specific pruning technologies beginning with the training for crown forms.
\end{abstract}

Key words: peach varieties, crown forms, caldron, slender spindle, growing habits

\section{Introduction}

Peach is a fruit species with worldwide importance, and its production is continuously increasing: in 1950, the overall production did not attain 2.5 million tons, whereas at the millennium it trespassed already 13 million tons. The present amount is around 16 million tons (Szabó, 2007). In Hungary, the last years experienced a drastic reduction, the 131800 t/year of 1972 diminished to 50 to 70 thousand tons in the 90-es, and the mean of the last 8 years was $50000 \mathrm{t}$. Also the acreage dwindled, having been 13000 ha in 1970 and 6000 ha now, as $6 \%$ of the fruit growing area. Hungary being on the northern limit of the peach growing area, the saving of quality causes concern. In order to keep the competitiveness of peach production, the intensity of the technology ought to be increased: plantings should be concentrated to favourable micro-regions, where optimal ecological conditions prevail and an intense, modern technology and high planting densities with regular irrigation, green pruning and fruit thinning are regularly applied.

Regarding the cultivation technology, the ancient caldron (kettle) type of crowns are still dominant in the region, in spite of the superiority of the slender spindles proved their superiority since the first successes of the 1970-es. Timon (1992, 1996) treated the methods of crown training and maintenance in his detailed study and proved their efficacy in achieving high yields. In spite of that, their use did not spread in the growing practice.

Timon (1996) claimed that the slender spindle is successful also in Hungary. A central axis and three fixed main branches are grown on a $40-60 \mathrm{~cm}$ high trunk. For maintaining the balance of growth, according to the principles of Zahn, the quotient of the branch/trunk ought to be 0.5 , the main axis/trunk: 0.85 , the main axis/branch: 1.75 .
According to the author, the peach is a "basitonic" shrub, we may modify these rules, to substitute the axis/trunk ratio, 0.85 , to 0.7 , furthermore, axis/branch ratio to $1.3-1.4$ being considered as ideal.

Gonda (2010) explains that the lack of a central axis in the caldron crown induces a vigorous reaction of the plant in spite of its "basitonic" tendency. In those trees, the nearly perpendicular shoots are dominating, which aggravates our task to spread the crown of the tree horizontally in order to improve the illumination of leaves. On the contrary, the crowns with a main axis grow more moderately and the harmony between growth and fruiting is more balanced.

The main advantages of a main central axis compared with the traditional (caldron) crowns are the higher efficacy of manual and mechanised labour, the better illumination of the crown, as well as a favourable covering of phytosanitary sprays (Miles \& Guarnaccia 1999). The bearing structures being in a more elevated position compared with the caldron crown, the late frost damages caused by radiation are less dangerous for the spindle crowns. The first yields ensue in the $3^{\text {rd }}$ year already, and last about 15 year long. And the quick returns let alone the change of varieties are also positive traits of those crowns. Timon (2000) proved that 8-year-old trees may yield $10-22 \mathrm{~kg}$ per tree, which means $11-22 \mathrm{t} / \mathrm{ha}$. The planting design of slender spindle plantations is $4.5 \times 2 \mathrm{~m}, 4 \times 2 \mathrm{~m}$ or $5 \times 1.5 \mathrm{~m}(1100-1300$ tree/ha).

Szalay (2009) suggested that one expedient from the crisis of overproduction would be the change of the assortment of varieties as an adaptation to the changing demands and widening the choice by the offer. The continuous appearance of new varieties necessitates the intrinsic examination of the main characters from the point of view of developing adequate training and pruning policies. 
In our examinations we wanted to take into account the differences between the traditional caldron form and the spindle crowns, moreover the growing characters of different peach varieties. Conscientious of that information, we may choose the best training and pruning technology in order to keep up with the requirements of an economically sound yield and the possibly highest quality.

\section{Materials and methods}

Measurements and observations have been performed in the plantation designed and maintained by István Gonda on the Experimental Horticultural Farm of the Debrecen University at Pallag, during the rest period of 2009/2010.

Table 1. The main parameters of the soil at Pallag, Horticultural Experimental Farm

\begin{tabular}{|l|l|}
\hline Sum of temperature & $3200-3300{ }^{\circ} \mathrm{C}$ \\
\hline Sunshine hours & 2045 hours/year \\
\hline Mean temperature of the year & $10-11^{\circ} \mathrm{C}$ \\
\hline Number of frosty days & $100-110$ days/year \\
\hline Precipitation The soil was a light sandy loam \\
\hline \multicolumn{2}{|c|}{ Characters of the soil } \\
\hline \multicolumn{2}{|c|}{$500-550 \mathrm{~mm}$} \\
\hline $\mathrm{Depth}$ & $0-60 \mathrm{~cm}$ \\
\hline $\mathrm{pH}$ & 5.6 \\
\hline $\mathrm{The}$ “ $\mathrm{Arany}$ " number of heaviness & 27 \\
\hline $\mathrm{Humus} \mathrm{content}$ & $0.62 \%$ \\
\hline $\mathrm{P}_{2} \mathrm{O}_{5}(\mathrm{mg} / \mathrm{kg})$ & 111 \\
\hline $\mathrm{K}_{2} \mathrm{O}(\mathrm{mg} / \mathrm{kg})$ & 395 \\
\hline $\mathrm{Mg}(\mathrm{mg} / \mathrm{kg})$ & 47 \\
\hline $\mathrm{Na}(\mathrm{mg} / \mathrm{kg})$ & 22 \\
\hline $\mathrm{Zn}(\mathrm{mg} / \mathrm{kg})$ & 1.0 \\
\hline $\mathrm{Mn}(\mathrm{mg} / \mathrm{kg})$ & 61.5 \\
\hline
\end{tabular}

The plantation is equipped with dropping irrigation, which completes the insufficient precipitation.

The aim of the study was the registration of the reaction of the peach varieties examined under the conditions of the two alternative crown types. The 8-year-old slender spindle trees were planted $4 \times 1.5 \mathrm{~m}$, and caldron trees $5 \times 3 \mathrm{~m}$, respectively. The sampled trees have been chosen according to their yields of the last season. Each variant of crown form $\mathrm{X}$ variety was represented by four trees each. Every tree is represented by 1500-2000 data.

The varieties examined (variety/rootstock):

- 'Early Redhaven' (peach rootstock)

_ 'Red Moon' (Gf 677)

- 'Suncrest' (peach rootstock)

_ 'Rich Lady' (Gf 677)

_ 'Silver King' (Gf 677)

_ 'Royal Glory' (Gf 677)

\section{Parameters raised on the caldron crowns:}

- Cross section area below of the trunk below the branches $\left(\mathrm{cm}^{2}\right)$

- Cross section area of the main branches at their base and at the length of $50 \mathrm{~cm}\left(\mathrm{~cm}^{2}\right)$

- Length of shoots $(\mathrm{cm})$

- Thickness of shoots at their half length (mm)

\section{Parameters raised on the spindle crowns:}

- Cross section area below of the trunk below the branches and at $50 \mathrm{~cm}$ length $\left(\mathrm{cm}^{2}\right)$

- Cross section area of the main branches at their base $\left(\mathrm{cm}^{2}\right)$

- Length and thickness of primary branches at the base $(\mathrm{cm})$

- Length of shoots $(\mathrm{cm})$

- Thickness of shoots at their half length (mm)

The original data have been converted to compound parameters, which are easier to compare. Those were:

- Length of shoots/cross section area $\left(\mathrm{cm} / \mathrm{cm}^{2}\right)$

- Number of shoots/cross section area of the respective branch $\left(\mathrm{db} / \mathrm{cm}^{2}\right)$

- The ratio of branches/main axis $(\mathrm{cm} / \mathrm{cm}$ or the Zahn index)

The special indices and the original data have been summarised, averaged according trees, varieties and crown forms, subsequently processed by variance-analysis.

\section{Results and discussion}

On Figure 1, it is evident that the cross section area was larger in the caldron crown trees than in the spindle tree. Substantial differences are found between the varieties. The largest differences appeared in 'Early Redhaven', 'Rich Lady' and 'Suncrest', where this attained 60-70\%.

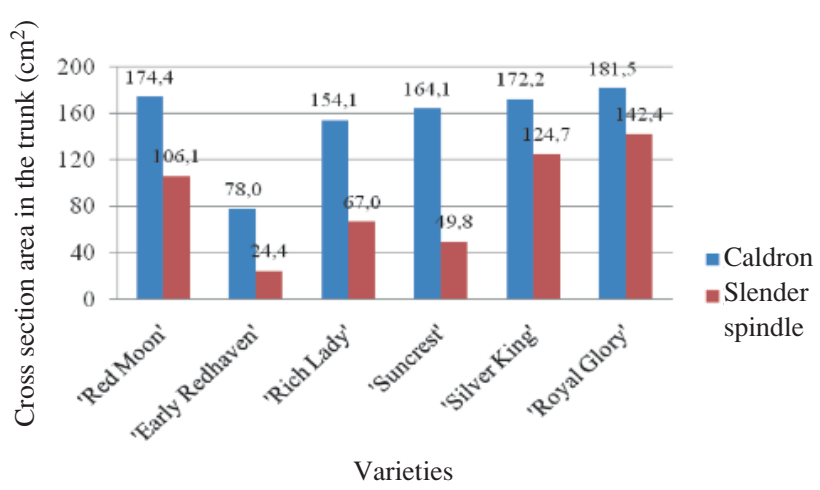

Figure 1. Cross section area in the trunk of peach varieties trained to caldron (blue) and to spindle (brown) crown (Debrecen-Pallag, 2009-2010) 
In Figure 2, the summarised specific lengths of the shoots per the cross section area are shown. Those show the "stimulating" effect of the caldron crowns, because in 4 varieties the spindly crowns were more advantageous and only in two varieties a little more advantageous.

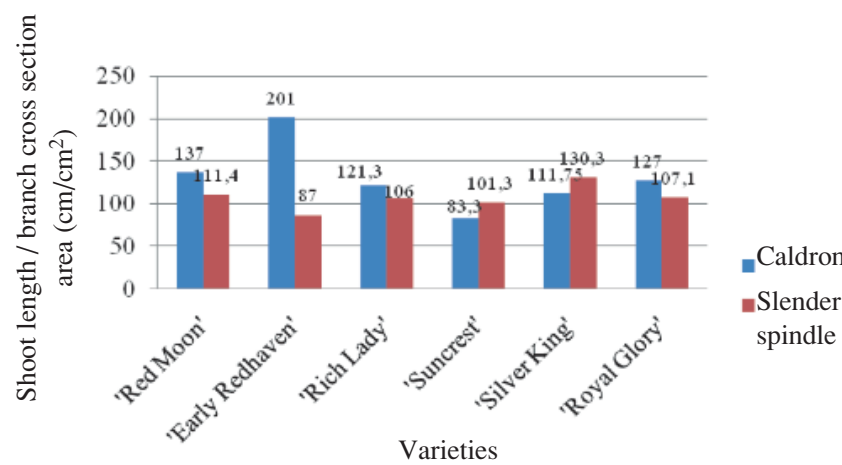

Figure 2. The sum of specific shoot length (per cross section area $\mathrm{cm} / \mathrm{cm}^{2}$ ) (Debrecen-Pallag, 2009-2010)

The specific number of shoots (Figure 3) shows the ability of ramification in the varieties with nearly similar tendencies as the length of shoots. The caldron crowns display the higher values like the shoot length. The former figures prove the higher vegetative growth indicators in the caldron crown.

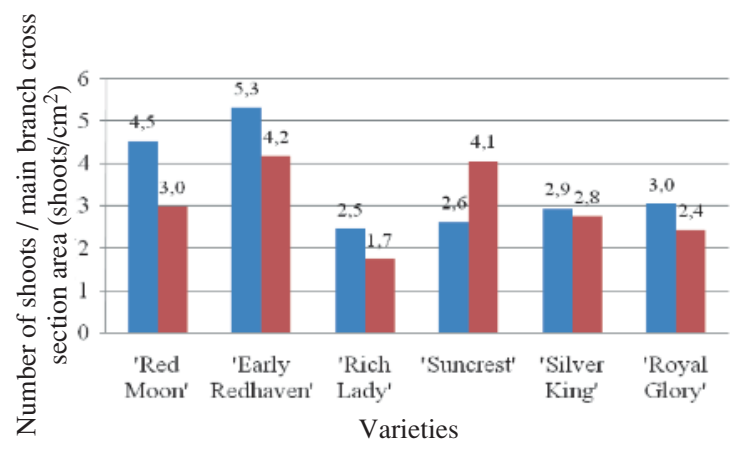

- Caldron

Slender

spindle

Figure 3. The specific number of shoots per cross section area $\left(\right.$ shoots $\left./ \mathrm{cm}^{2}\right)$ in varieties and crown types (Debrecen-Pallag, 2009-2010)

Figure 4 shows the mean length of shoots as being also stimulated by the training to spindle crown in 4 varieties. It is evident that the stimulation of the spindle crown is recognised in the mean length of the shoots too. Compared with the former figures, we may conclude that the difference in shoot length is less important than in the number of shoots.

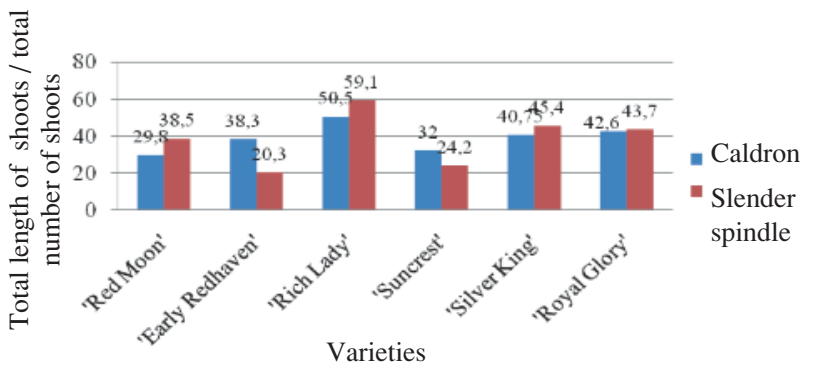

Figure 4. The mean length of shoots (cm/number of shoots) in varieties and crown forms (Debrecen-Pallag, 2009-2010)
Besides the mean length of shoots, we may consider the condition of the shoots, which is expressed in their mean volume (Figure 5). The advantage of the spindle crown over the caldron crown is clearly expressed in 4 varieties, whereas the caldron crowns produced small differences. The large value of the volumes, as a product of length times thickness, were much more convincing than the length and thickness alone. The spindle crown secured better conditions to optimal shoot thickness too.

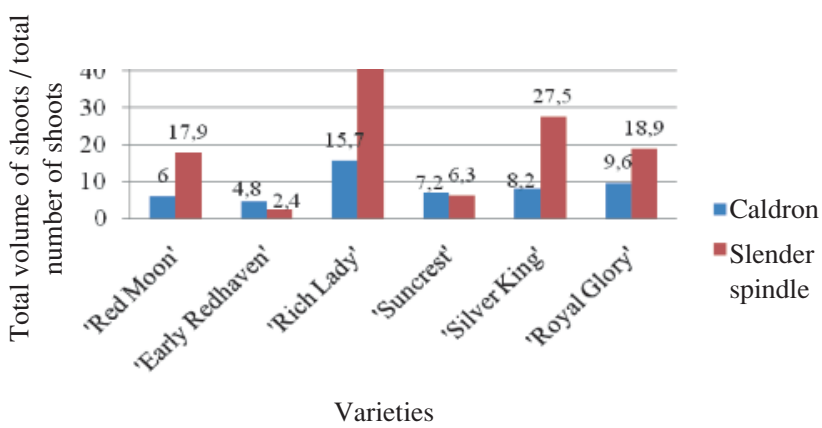

Figure 5. Mean volume of shoots $\left(\mathrm{cm}^{3}\right)$ in varieties a crown types (Debrecen-Pallag, 2009-2010)

The ratio of the trunks and the lower branches is shown in Figure 6. It should be remarked that in the case of caldron crowns, all branches are considered, whereas in the spindle crowns only the 3-5 branches are measured. The data allow the conclusion that in the caldron crowns, the Zahn-index was higher than in the spindle crowns, which means that the caldron crowns, the branches are relatively thicker at the beginning. In the spindle crowns, the existence of a main axis moderates the thickness of the branches.

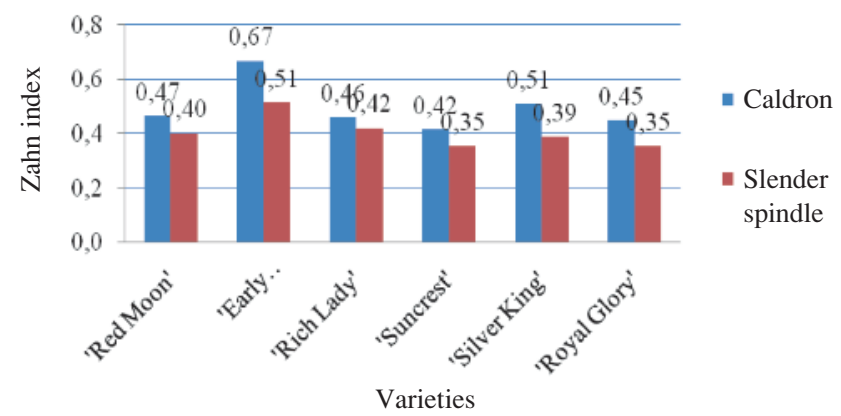

Figure 6. The ratio of the cross section area of trunk and the branches (Zahn index) in the crown forms (caldron and spindle) (Debrecen-Pallag, 2009-2010)

In the spindle crowns, the thickness of the branches is compared according to their sequence (Figure 7). In the majority of varieties, the Zahn index of the branches in the upward going sequence increased gradually. In 'Rich Lady' and 'Suncrest' varieties the increasing tendency was clear, whereas in 'Royal Glory', the increment was moderate. In 'Red Moon', the stronger branches were located around the 
second third length of the axis, in 'Silver King' this region was the weaker. In 'Early Redhaven' spindle crowns the growth was weak and did not attain the $250 \mathrm{~cm}$ height. This variety seems to be exceptionally not suitable for the slender spindle.

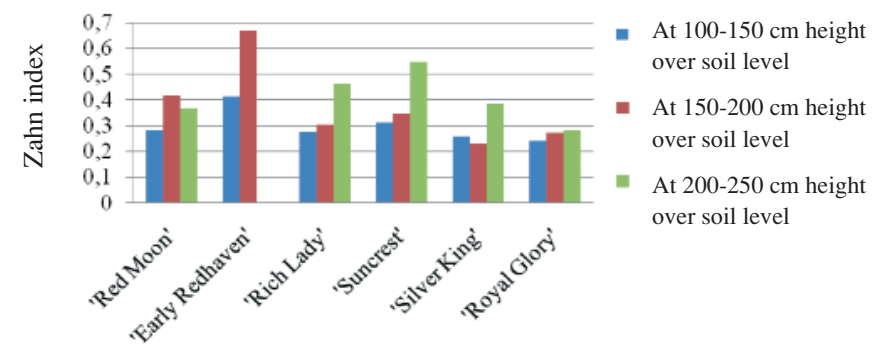

Figure 7. The trunk/branch relation of primary branches (Zahn index) in the spindle crowns of peach varieties at different height over the soil level (Debrecen-Pallag, 2009-2010)

In Figure 8, measurements at different heights prove that the tapering of the central axis is not continuous. In some varieties ('Silver King', 'Suncrest') it is linear, in others ('Red Moon', 'Royal Glory') there are interruptions in the evenness.

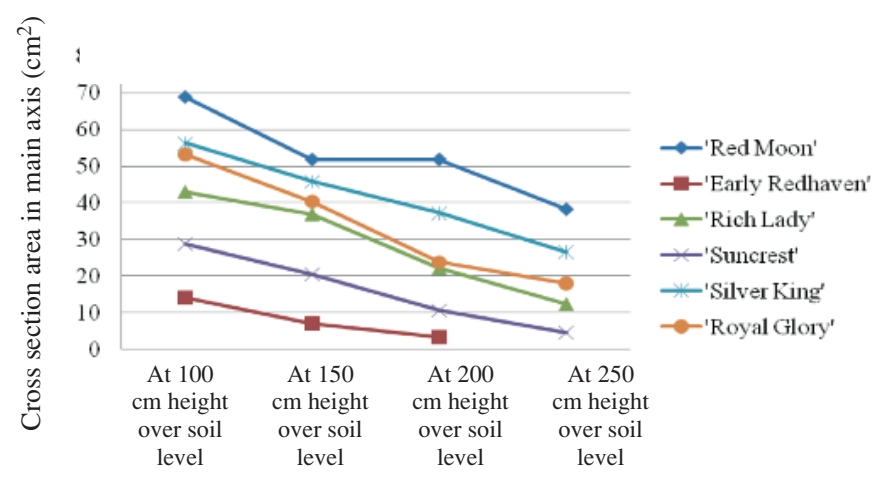

Figure 8. The diminution of the cross section area in the main axis as a function of height in spindle crowns of peach varieties

(Debrecen-Pallag, 2009-2010)

The amount of trimming after a winter pruning was measured (Figures 9-10). In general, the slender spindle crowns produced less trimming than the caldron crowns. Less trimming

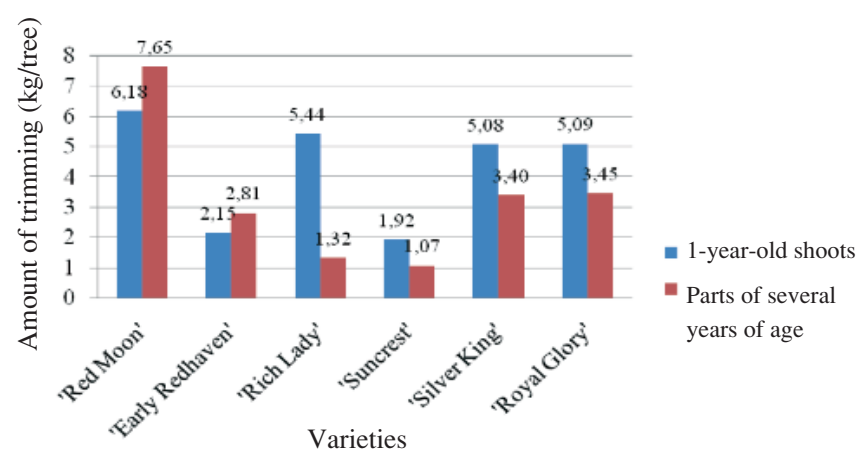

Figure 9. The amount of trimming in caldron crown trees after winter pruning distinctly one year old and elder parts (blue and brown resp.) (kg/tree) (Debrecen-Pallag, 2009-2010)

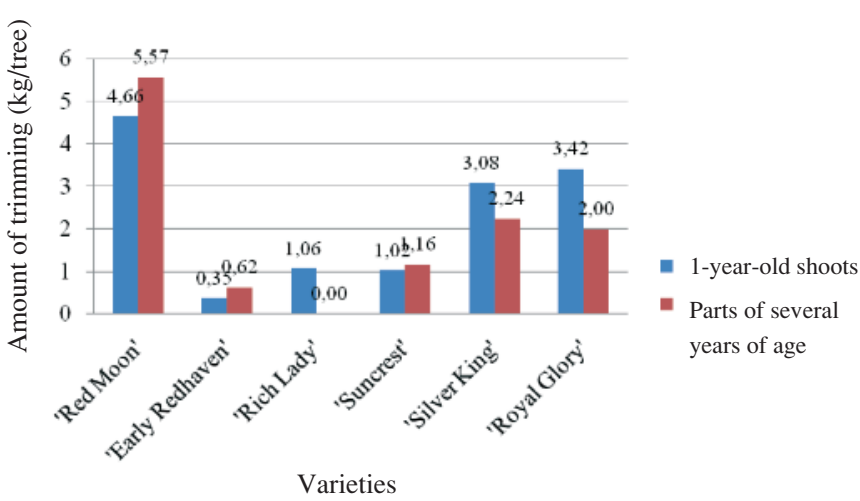

Figure 10. The amount of trimming in spindle crown trees after winter pruning distinctly one year old and elder parts (blue and brown resp.) (kg/tree) (Debrecen-Pallag, 2009-2010)

means less scars on the tree, and the danger of infections is diminished. On the basis of Figures 6,9 and 10, we may state that on slender spindles the sawing is less necessary.

\section{Conclusion}

Our results suggest that with the crown forms the growing intensity of peach varieties changed remarkably as being compared trees of the same age. This is a consequence of differences regarding the ramification and the number of growing points of trees as well as the length and orientation (nearly horizontal, oblique or perpendicular position) of shoots. The caldron form compared with the spindle means a kind of "simplification" because the fruiting structures appear at a relatively uniform height (over the soil level) on nearly identical length, thickness and angle of position. The slender spindle, on the contrary, developed a dominant central axis as a continuation of the trunk, and the ramification produces shorter and thinner (tapering and shortening at an upward sequence) branches approaching more or less the horizontal position. The existence or lack of an axis and the spatial order (length, thickness and angle) are acting on the growing attitudes. The superior vegetative efficacy of the caldron crown is due to the lack of a central axis of the spindle crown. It is true all the same because the peach tends to be a shrub with a "basitonic" type of ramification. The perfect lack of a central axis induces after many years growth of "substitute" axes by many perpendicular long shoots. On the slender spindle crown, the growth of shoots is much more equalised.

The Zahn-index of the relations of cross section areas has higher values in the caldron crowns than in the spindle crowns. With high trunk values, also the branches had higher values. According to our opinion, the harmonisation of growth and fruiting would be even more effective if the number of main (primary) branches of the caldron would more than $3-4$, in order to equalise the growing vigour. The same result would be expected with the multiplication of growing points by branches of second, third, etc. order. The amount and quality of the trimming proves that the caldron 
crowns ought to be treated by much more severe pruning in order to keep the foliage well illuminated. Not only a part of the shoots are eliminated but also older wood. In the slender spindle crown, much less and preferably one-year-old shoots are pruned.

The comparison of different varieties on the basis of the Zahn-indices calls our attention on the variety-specific peculiarities. On the tapering main axis, proportionally thick branches should be raised, which means that the thicker the axis relaively thicker branches ought to be allowed.

Finally, we should remind the reader that after our examination, a severe cold spell of les than $-20^{\circ} \mathrm{C}$ hit the plants. As a result, the low stature caldron trees lost near $90 \%$ of the flower buds, whereas the slender spindle trees only $50 \%$. This episode strengthen our conviction of preferring slender spindle crowns at growing sites threatened by winter and spring frosts.

\section{References}

Gonda, I. (2010): Csonthéjas gyümölcsfák metszése. Debreceni Egyetem AMTC Kutatási és Fejlesztési Intézet. Gonda István Betéti Társaság

Miles \& Guarnaccia, R. (1999): High Density Peach Production in Ontario. New York Fruit Quarterly, 7: 4.

Szabó, Z. (2007): Merre tart a világ őszibarack termesztése? Kertészet és Szőlészet, 56. (41): 14-16.

Szalay, L. (2009): Csak a szép külső számít. Kertészet és Szőlészet, 58. (31): 17-19.

Timon, B. (1992): Őszibarack 3., átdolgozott kiadás. Mezőgazda Kiadó. Budapest

Timon, B. (1996): Ôszibarack karcsú orsó - az intenzitásnövelés egy lehetséges útja. Új Kertgazdaság, 2. (3): 1-11.

Timon, B. (2000): Ôszibarack. Mezőgazda Kiadó, Budapest 